\title{
APLIKASI METODE BREAK EVEN POINT PADA DESAIN TUNGKU GASIFIKASI BIOMASSA MULTI BURNER SEKAM PADI SEBAGAI PENGGANTI MINYAK TANAH DAN KAYU BAKAR MENUJU MASYARAKAT MANDIRI ENERGI DI DAERAH PULAU KECIL
}

\author{
Made Wijana ${ }^{1}$, I Wayan Joniarta ${ }^{2}$ Dan Nurchayati ${ }^{3}$ \\ 1,2,3 Jurusan Teknik Mesin,Universitas Mataram \\ JI Majapahit no.62 Mataram Lombok NTB \\ Email.Wijanamd23@yahoo.co.id
}

\begin{abstract}
ABSTRAK
Dimasyarakat pulau kecil sering mengalami kesulitan dalam memasak karena langka dan mahalnya minyak tanah dan kayu bakar. Sedangkan tungku gasifikasi yang telah diteliti dan diapikasikan (gasifikasi biomassa single burner), meskipun hasilnya sudah bagus, tetapi sulit diterima dimasyarakat karena pemasakan dilakukan langsung diatas tungku, sehingga keamanannya lemah karena bahaya terkena panas dinding tungku dan rancangan yang tinggi mengakibatkan kekhawatiran masyarakat, disamping itu sifatnya tidak bisa kontinyu dan pengapiannya tidak bisa dilakukan secara cepat, karena tungku dengan burner dirancang menjadi satu. Untuk itu maka pada program ini perlu dilakukan penelitian bagaimana merancang suatu tungku gasifikasi biomassa yang murah, mudah dan aman dalam pengoperasiannya dengan merancang bentuk tungku yang memiliki multi burner dengan letak tungku dan burnernya terpisah, bagaimana merancang saluran penghantar dari tungku ke burner,dan bentuk burner yang sesuai sehingga dengan jauhnya tungku dan burner pengapian, keamanan dan kenyamanan masyarakat pulau kecil pengguna energi terbarukan (gasifikasi biomassa) terjamin, sehingga masyarakat mandiri energy di pulau kecil dapat diwujudkan.

Metode yang digunakan dalam penelitian ini adalah metode rekayasa nilai untuk memilih satu alternatif modifikasi pada tungku briket arang biomassa dan menganalisanya melalui lima tahap rencana kerja yang meliputi (1) tahap informasi, (2) tahap kreatif, (3) tahap analisa, (4) tahap pengembangan dan (5) tahap presentasi.

Pada tahap analisa, dilakukan analisa terhadap 8 alternatif modifikasi ditambah 1 desain awal, dimana desain awal digunakan sebagai patokan dalam penilaian performansi. Hasil penentuan nilai pada tahap pengembangan diperoleh bahwa alternatif modifikasi ke-7, mempunyai nilai tertinggi yaitu1,142 dengan performansi 427,83, dan biaya Rp. 1.850.000,0. Alternatif ini memberikan keuntungan antara lain, kemudahan operasionalnya sangat meningkat dapat dilakukan pengisian berulang tanpa mengganggu nyala api (sistem kontinyu), dan pemadaman api dapat dilakukan dengan cepat tanpa pembongkaran tungku (semi otomatis), pengguna tidak perlu memasak diatas reaktor gasifikasi yang panas dan tinggi, karena tungku ini didesain dapat memasak diatas burner yang jauh dari reaktor gasifikai, kecepatan pemasakan meningkat (mendidihkan 2 It air dengan waktu 7 menit), pencemaran menurun dan tidak terjadi bau menyengat.

Tungku gasifikasi multiburner mempunyai nilai ekonomi tinggi karena kinerjanya hampir sama dengan tungku minyak tanah dan biaya operasionalnya sekitar $1 / 3$ dari tungku minyak tanah, untuk memasak 2 It air, menggunakan minyak tanah sekitar 1/10 It (Rp. 1300), dengan tungku single burner membutuhkan sekam $2 \mathrm{~kg}$ (Rp. 400) dan dengan tungku ini membutuhkan $2 \mathrm{~kg}$ sekam (Rp.400), dengan melihat hal tersebut, maka tungku gasifikasi multibuerner, dari segi ekonomi sangat prospek untuk dikembangkan di masyarakat. Sebagai salah satu alternative pengganti tungku gasifikasi single burner, tungku minyak tanah dan kayu bakar dan sebagai salah satu agen dari green technology guna menciptakan masyarakat mandiri energi khususnya di pulau-pulau kecil
\end{abstract}

Kata kunci: Modifikasi, Tungku gasifikasi multiburner , Rekayasa nilai,

\section{PENDAHULUAN}

Semakin menipisnya cadangan minyak dunia yang menyebabkan harga bahan bakar minyak (BBM) terus melambung. Bagi daerah-daerah yang masyarakatnya tergantung pada minyak tanah, dipastikan akan terjadi suatu kemunduran karena aktivitas kehidupan 
akan lebih lambat, lemahnya aktifitas usaha, serta banyak lagi yang tidak mampu dilakukan akibat ketiadaan minyak tanah. Seperti halnya Pulau Lombok khususnya di lombok barat, Kabupaten Lombok Barat adalah salah satu dari 9 kabupaten/kota di NTB yang terbagi menjadi lima belas Kecamatan Rumah tangga di daerah tersebut hampir semuanya menggunakan satu diantara 2 jenis bahan bakar yaitu : minyak tanah dan Kayu Bakar (BPS, 2006). Kedua bahan bakar ini bila dibandingkan dengan gasifikasi sekam padi, biayanya jauh lebih mahal. Biaya yang dikeluarkan untuk memasak selama 2 jam, dengan minyak tanah Rp.6.000,- dengan kayu bakar Rp.4.000,- dan dengan sekam padi hanya Rp.800,-(lihat bagian sekam padi). Dilihat dari hal tersebut, masyarakat sangat tergantung pada minyak tanah dan kayu bakar. Kondisi ini akan bertolak belakang dengan program pemerintah dalam rangka peningkatan tarap hidup masyarakat. Kondisi ini menyebabkan masalah yang serius yang perlu diatasi. Diantaranya dengan menggali potensi energi alternative yang diperbaharui seperti : energi biomassa, energi angin, matahari dan gelombang laut telah mulai dilirik.

Untuk pemanfaatan energi biomassa, potensi bahan bakunya sangat murah dan melimpah serta memiliki kandungan energi cukup tinggi diantara biomassa tersebut adalah sekam padi. Potensi sekam padi dari segi jumlah dan kandungan energinya sangat besar. Di Indonesia, khususnya di NTB, dari produksi padi Provinsi NTB tahun 2008 ditargetkan 1.723.991 ton gabah kering giling (GKG), besarnya potensi limbah sekam padi NTB sekitar 344.798 ton dan sebagian besar masih belum digunakan dan cenderung sebagai polutan (Bank Indonesia, 2008) dengan kandungan energi 5400 $\mathrm{kkal} / \mathrm{kg}$ [1].. Hal ini kalau termanfaatkan dengan baik akan dapat menjadi energi alternatif pengganti minyak tanah dan kayu bakar.

Walaupun telah banyak dibuat alatalat untuk memanfaatkan energi alternatif seperti pembuatan tungku gasifikasi sekam padi yang selama ini dikenalkan, tetapi tungku-tungku gasifikasi tersebut belum banyak digunakan sebagai pengganti minyak tanah oleh masyarakat dan malah ada penolakan. Yang menjadi kendala utama tidak digunakannya tungku gasifikasi berbahan bakar sekam padi (single \& direct burner) adalah karena keamanannya lemah dan penggunaanya kurang nyaman dan kurang praktis [2]. Keamanannya lemah karena bahaya terkena panas dinding tungku karena pemasakan langsung dilakukan diatas tungku, dan rancangan tungku yang tinggi mengakibatkan kekhawatiran tumpahnya masakan. Kenyamanan kurang karena pembongkaran dan pengisian langsung dilakukan di tungku, sehingga peletakan tungku tidak bisa dilakukan diruang tertutup. Dan ketidakpraktisan diakibatkan karena pemasukan bahan baku tidak bisa kontinyu, pemadaman tidak bisa dilakukan secara cepat, karena tungku dengan burner dirancang menjadi satu. Satu tungku hanya bisa digunakan untuk satu keperluan. Untuk itu maka pada program ini perlu dilakukan penelitian bagaimana merancang suatu tungku gasifikasi biomassa yang murah, mudah dan aman dalam pengoperasiannya dengan merancang bentuk tungku yang memiliki multi burner dengan letak tungku dan burnernya terpisah, bagaimana merancang saluran penghantar dari tungku ke burner,dan bentuk burner yang sesuai sehingga dengan jauhnya tungku dan burner pengapian, sehingga disamping dalam pengoperasiannya praktis, keamanan dan kenyamanan masyarakat pedesaan pengguna energi terbarukan (gasifikasi biomassa) terjamin.

\section{METODE PENELITIAN}

Didalam Penelitian ini dibagi menjadi tujuh tahap penelitian yaitu:

\subsection{Tahap persiapan}

Pada tahap ini dilakukan perumusan permasalahan dan identifikasi tujuan penelitian, dilanjutkan dengan studi literatur yang meliputi sumber buku dan penelitian sebelumnya. Selanjutnya dilakukan studi lapangan berupa observasi, interview untuk mendapatkan gambaran kondisi dilapangan Pada poin 2.2 sampai dengan 2.6 adalah merupakan implementasi dari Rencana Kerja

Rekayasa Nilai (Value engineeering) yang dikenal dengan Rencana Kerja Lima Tahap (five phase job plan) Rekayasa Nilai

Rencana kerja dari rekayasa nilai yang dikembangkan pada penelitian ini terdapat (5) lima tahap kerja, yang mana dalam implementasinya kelima tahap kerja tersebut saling mendukung satu dengan lainnya secara energies [3]. 


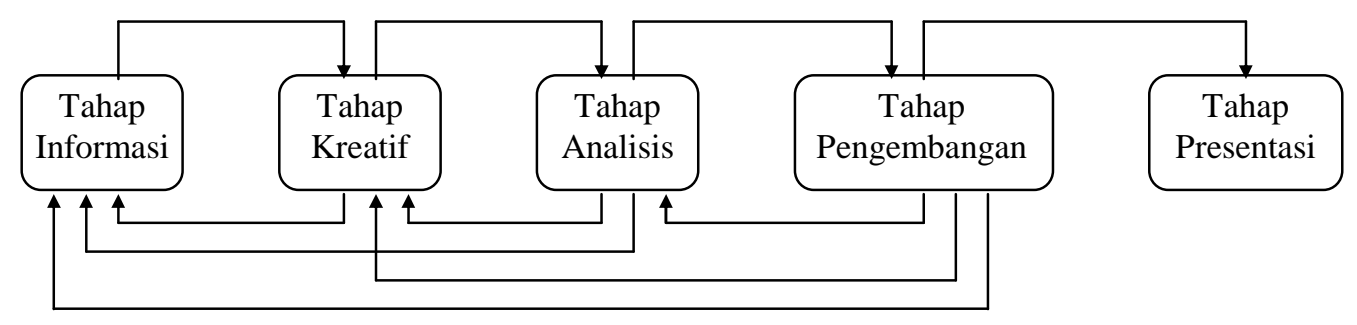

Gambar 1 Hubungan Kerja Lima Tahap(five phase job plan) Rekayasa Nilai

Adapun ke lima tahap rencana kerja (five phase job plan), tersebut yaitu dapat dijelaskan sebagai berikut :

\subsection{Tahap informasi}

Di dalam tahap informasi merupakan tahap awal dari proses kerja lima tahap dengan tahapan yang meliputi pengumpulan sebanyak-banyaknya informasi yang berkaitan dengan produk atau alat yang diteliti. Tahap informasi memiliki dua tujuan yaitu: (1) Untuk memperoleh pengertian yang mendalam mengenai sistem, struktur atau item-item yang dipelajari dan (2) Untuk memberi gambaran yang jelas tentang nilai dengan menggunakan pembahasan fungsional dan perkiraan biaya untuk mencapai fungsi utama

Langkah awal dari tahap informasi adalah menentukan terlebih dahulu bagianbagian mana yang akan dianalisa, dan meninggalkan yang tidak diperlukan. Dimana bagian tersebut merupakan bagian yang paling efektif dan efisien untuk dilakukan studi.

Pada tahap informasi inilah semua fungsifungsi ditetapkan termasuk fungsi utamanya dengan melakukan analisa fungsi, dan kemudian digambarkan dalam bentuk diagram yang disebut diagram Function Analysis System Technique (FAST), seperti yang telah dijelaskan sebelumnya.

\subsection{Tahap kreatif}

Tahap kreatif ini ditampilkan alternatif awal (desain awal) dan alternatif usulan berupa beberapa alternatif utama untuk selanjutnya dilakukan kombinasi antara alternatif utama yang diusulkan sehingga diperoleh beberapa alternatif modifikasi. dan juga memunculkan beberapa kriteria yang diperlukan dalam penilaian alternatif modifikasi. Kriteria dan alternatif yang digunakan ini sebagai acuan untuk menyusun kuisioner banding berpasangan dengan metode AHP (expert choice) untuk selanjutnya disebarkan kepada orang yang expert dibidang yang diteliti ini.

\subsection{Tahap analisa}

Tujuan tahapan analisa adalah mengevaluasi alternatif-alternatif yang dihasilkan pada tahap kreatif. Evaluasi alternatif pada tahap ini dilaksanakan untuk menentukan alternatif terbaik diantara alternatif yang ada, yang memiliki potensi terbesar untuk mengurangi biaya.

Pada tahap ini dilakukan analisa keuntungan dan kerugian masing-masing alternatif, dilanjutkan dengan Melakukan analisa matrik kelayakan yang meliputi beberapa langkah sebagai berikut :

- Melakukan penyusunan altenatif dan penilaian terhadap setiap kriteria dan selanjutnya dilakukan pengurutan berdasarkan nilai terbesar (ranking). Setelah dilakukan pengurutan, maka alternatif yang memiliki nilai terbesar dipilih untuk dianalisa lebih lanjut sedangkan alternatif yang lainnya ditinggalkan.

- Melakukan analisa perbandingan berpasangan

Analisa ini dilakukan untuk menentukan bobot tiap-tiap kriteria yang dibandingkan, kemudian dilakukan uji konsistensi, bila sudah memenuhi syarat maka bobot kriteria tersebut digunakan untuk perhitungan performansi pada analisa evaluasi.

- Melakukan analisa matrik evaluasi

Analisa ini diawali dengan perkalian bobot tiap kriteria dengan nilai rekapitulasi alternatif tiap kriteria, . hasil akhir dari tahap analisa (Analysis phase) ini adalah penentuan nilai performansi dari alternatif yang terpilih.

\subsection{Tahap pengembangan}

Pada tahap ini, dilakukan dua langkah kerja yaitu:

- Melakukan perhitungan biaya yang dikeluarkan untuk memodifikasi alternatif terpilih

- Melakukan perhitungan nilai (value). alternatif terpilih

\subsection{Tahap presentasi}

Tahap presentasi ini adalah merupakan tahap untuk mempresentasikan 
atau menjelaskan alternatif terpilih yang didasarkan nilai (value) yang tertinggi. Langkah yang dilakukan yaitu

- Mempresentasikan atau menjelaskan alternatif modifikasi Tungku terpilih (terbaik)

- Membandingkan keuntungan dan kerugian desain awal (alternatif awal) dan alternatif modifikasi terbaik

Oleh karena tahap presentasi ini merupakan tahap akhir dari lima tahap rencana kerja (five phase job plan) Rekayasa Nilai. Maka tahap presentasi harus dapat memberikan keyakinan pada pihak manajemen atau pengambil keputusan, bahwa alternatif terpilih ini dapat di implementasikan, merupakan pilihan terbaik, dan menguntungkan.

\subsection{Kesimpulan dan Saran}

Tapa tahap ini diambil beberapa poin untuk disimpulkan. Dan beberapa saran yang guna penyempurnaan pada penelitian yang telah dilakukan

\section{HASIL PENELITIAN}

\subsection{Pembuatan Diagram FAST}

Dalam menentukan analisis fungsi teknis dari Tungku Gasifikasi biomassa sekam padi Multiburner tersebut dilakukan dengan metode Function Analisys System Technique atau lebih dikenal dengan singkatan FAST diagram, diagram ini berguna untuk berkomunikasi secara teknis.

\subsection{Tahap Kreatif}

Tahap kreatif ini ditampilkan alternatif awal (desain awal) dan alternatif usulan berupa beberapa alternatif utama untuk selanjutnya dilakukan kombinasi antara alternatif utama yang diusulkan sehingga diperoleh beberapa alternatif modifikasi dan juga memunculkan beberapa kriteria yang diperlukan dalam penilaian alternatif modifikasi. Kriteria dan alternatif yang digunakan ini sebagai acuan untuk menyusun kuisioner banding berpasangan dengan metode AHP (expert choice) untuk selanjutnya disebarkan kepada orang yang expert dibidang yang diteliti ini.

\section{Penentuan Kriteria Penilaian}

Setelah melakukan studi literature dan diskusi dengan para expert bidang tungku gasifikasi,maka diperoleh 7 kriteria penilaian alternatif modifikasi dan 9 alternatif yang terdiri dari 1 alternatif awal dan 8 alternatif modifikasi. Adapun Kriteria dan alternatif yang digunakan dalam modifikasi Tungku gasifikasi sekam padi pada penelitian ini yaitu :

Tabel 1. Kriteria Penilaian

\begin{tabular}{|c|l|}
\hline No & \multicolumn{1}{|c|}{ Kriteria } \\
\hline 1 & Kemudahan Operasional (pemakaian) (KO) \\
\hline 2 & Kemudahan mendapatkan bahan (KB) \\
\hline 3 & Kemudahan pemeliharaan (PM) \\
\hline 4 & Biaya pemeliharaan (BP) \\
\hline 5 & Rendahnya Pencemaran (RP) \\
\hline 6 & Kekuatan konstruksi (KK) \\
\hline 7 & Kecepatan pemasakan (KP) \\
\hline
\end{tabular}

\section{Penentuan Alternatif Modifikasi}

Pada tahap ini dimunculkan beberapa alternatif yang dapat membantu untuk melakukan perbaikan pada tungku gasifikasi sekam padi yang ada, ide untuk proses kreatif dilakukan dengan metode diskusi oleh para pengguna dan pengerajin yang terlibat langsung pada proses diskusi ini. Setelah dilakukan diskusi terhadap kemungkinan modifikasi tungku gasifikasi sekam padi dengan 5 pakar tungku, maka diperoleh beberapa alternatif gagasan adalah sebagai berikut:

Tabel 2. Alternatif Modifikasi

\begin{tabular}{|c|l|}
\hline Alternatif & \multicolumn{1}{c|}{ Keterangan } \\
\hline $\mathbf{0}$ (Awal) & \multicolumn{1}{c|}{ Tanpa perbaikan } \\
\hline 1 & $\begin{array}{l}\text { Mengganti type gasifikasi dari single } \\
\text { burner dengan multibuener (alternatif 1) }\end{array}$ \\
\hline 2 & $\begin{array}{l}\text { Mengganti sistem penyembur angin } \\
\text { type tudung berlubang (alternatif.2) }\end{array}$ \\
\hline 3 & $\begin{array}{l}\text { Mengganti kipas menjadi blower } \\
\text { dengan pengatur angin (alt. 3) }\end{array}$ \\
\hline 4 & $\begin{array}{l}\text { Kombinasi antara alternatif 1 dan } \\
\text { alternatif 2 }\end{array}$ \\
\hline 5 & $\begin{array}{l}\text { Kombinasi antara alternatif 1 dan } \\
\text { alternatif 3 }\end{array}$ \\
\hline 6 & $\begin{array}{l}\text { Kombinasi antara alternatif 2 dan } \\
\text { alternatif 3 }\end{array}$ \\
\hline 7 & $\begin{array}{l}\text { Kombinasi antara alternatif 1,2 dan } \\
\text { alternatif 3 }\end{array}$ \\
\hline 8 & $\begin{array}{l}\text { Mengganti tebal dinding dari 2 mm } \\
\text { menjadi 1 mm }\end{array}$ \\
\hline
\end{tabular}

\section{Tahap Analisa}

Pada tahap ini mekanisme yang dilakukan adalah untuk mengevaluasi alternatif yang timbul pada tahap kreatif adalah dengan menggunakan analisa keuntungan dan kerugian pada alternatif yang timbul dan dilanjutkan dengan pembobotan untuk menentukan prioritas kriteria dan perhitungan performansi dengan matrik evaluasi terhadap alternatif yang muncul, untuk menjelaskan hal tersebut 
diatas berikut ini dijabarkan untuk masingmasing mekanisme tersebut:

Tabel 3. Rekapitulasi Frekwensi Tingkat Kepentingan

\begin{tabular}{|c|l|c|c|c|c|c|}
\hline \multirow{2}{*}{ No Kriteria } & \multicolumn{2}{|c|}{ Frekwensi Responden Tingkat Kepentingan } & \multirow{2}{*}{ Rank } \\
\cline { 3 - 6 } & & T & CT & CR & R & \\
\hline \hline 1 & Kemudahan Operasional (pemakaian) $(\mathrm{KO})$ & 9 & 3 & 2 & 0 & $\mathrm{~T}$ \\
\hline 2 & Kemudahan mendapatkan bahan (KB) & 3 & 9 & 2 & 0 & $\mathrm{CT}$ \\
\hline 3 & Kemudahan pemeliharaan (PM) & 2 & 5 & 7 & 0 & $\mathrm{CR}$ \\
\hline 4 & Biaya pemeliharaan (BP) & 4 & 4 & 6 & 0 & $\mathrm{CR}$ \\
\hline 5 & Rendahnya Pencemaran (RP) & 4 & 7 & 3 & 0 & $\mathrm{CT}$ \\
\hline 6 & Kekuatan konstruksi (KK) & 3 & 7 & 4 & 0 & $\mathrm{CT}$ \\
\hline 7 & Kecepatan pemasakan (KP) & 10 & 2 & 2 & 0 & $\mathrm{~T}$ \\
\hline
\end{tabular}

\subsection{Pembobotan Kriteria}

Alternatif dan kriteria yang ada didalamnya untuk masing-masing alternatif maupun kriteria .Bobot diberikan berdasarkan pendapat ekspert dan dilakukan dengan membandingkan antar kriteria dan alternatif sehingga diketahui masing-masing prioritas dari kriteria.

Tabel 3 Jumlah Matrik Kolom Banding Berpasangan

\begin{tabular}{|c|l|c|c|c|c|c|c|c|}
\hline No & \multicolumn{1}{|c|}{ Kriteria } & KO & KB & PM & BP & RP & KK & KP \\
\hline \hline 1 & Kemudahan Operasional (pemakaian) (KO) & 1 & 3.57631 & 2.67183 & 3.69513 & 2.13717 & 3.25045 & 0.70711 \\
\hline 2 & Kemudahan mendapatkan bahan (KB) & 0.27962 & 1 & 0.73677 & 1.54258 & 0.61980 & 0.87987 & 0.39994 \\
\hline 3 & Kemudahan pemeliharaan (PM) & 0.37427 & 1.35727 & 1 & 2.34878 & 0.87987 & 1.73851 & 0.34474 \\
\hline 4 & Biaya pemeliharaan (BP) & 0.27063 & 0.64826 & 0.42575 & 1 & 0.43826 & 0.84834 & 0.35651 \\
\hline 5 & Rendahnya Pencemaran (RP) & 0.46791 & 1.61343 & 1.13653 & 2.28173 & 1 & 1.99257 & 0.57521 \\
\hline 6 & Kekuatan konstruksi (KK) & 0.30765 & 1.13653 & 0.57521 & 1.17877 & 0.50186 & 1 & 0.42380 \\
\hline 7 & Kecepatan pemasakan (KP) & 1.41421 & 2.50034 & 2.90072 & 2.80496 & 1.73851 & 2.35963 & 1 \\
\hline \hline & Jumlah matrik berpasangan & 4.11429 & 11.83215 & 9.44682 & 14.85194 & 7.31548 & 12.06938 & 3.80731 \\
\hline
\end{tabular}

Pada tabel diatas ditunjukkan perbandingan berpasangan antar kriteria dalam masingmasing alternatif, perbandingan berpasangan tersebut diisi oleh ahli dibidang tungku gasifikasi biomassa. Dari perbandingan tersebut didapatkan besarnya bobot untuk masing-masing kriteria. Bobot kriteria akhir (level 2) yang berupakan tingkat kepentingan kriteria tersebut berguna dalam perhitungan performansi pada analisa evaluasi.

Tabel 4. Tingkat Kepentingan (Bobot) Kriteria

\begin{tabular}{|c|c|c|c|}
\hline \multirow{2}{*}{ No } & \multirow{2}{*}{ Kriteria } & \multicolumn{2}{|c|}{ Bobot } \\
\cline { 3 - 4 } & & Level 1 & Level 2 \\
\hline \hline 1 & KO & 0,2606 & 1,86263 \\
\hline 2 & KB & 0,0853 & 0,60403 \\
\hline 3 & PM & 0,1178 & 0,83570 \\
\hline 4 & BP & 0,0653 & 0,46089 \\
\hline 5 & RP & 0,1396 & 0,98875 \\
\hline 6 & KK & 0,0820 & 0,57955 \\
\hline 7 & KP & 0,2495 & 1,79210 \\
\hline \hline
\end{tabular}

\subsection{Uji Konsistensi}

Uji konsistensi pada penelitian ini menggunakan nilai batas yang diijinkan
Saaty pada metode AHP (expert choice) yang digunakan dalam penelitian ini. Uji konsistensi ini dilakukan dengan membandingkan nilai konsistensi ratio (CR) dari hasil perhitungan dengan nilai $C R$ yang diijinkan saaty. Berdasarkan analisa data diperoleh nilai $\mathrm{CR}=0,0131(1,31 \%)$, hal ini menunjukkan nilai kriteria yang diperoleh konsisten karena tidak melebihi batas yang diijinkan yaitu sama atau lebih kecil $(\leq)$ dari $10 \%$. Hal ini menunjukkan bahwa responden dalam mengisi kuisioner banding berpasangan sudah konsisten.

\subsection{Performansi Alternatif}

Pada tahap ini performansi alternatif dihasilkan dari penjumlahan tiap baris dari hasil perhitungan dengan mengalikan bobot pada tiap kriteria dengan nilai rekap evaluasi alternatif tiap kriteria. Rekap nilai alternatif tiap kriteria ini akan dikalikan dengan hasil bobot dari masing-masing kriteria, setelah masing-masing baris hasil dari perkalian tersebut dijumlahkan diperoleh nilai performansi dari masing-masing alternatif, beserta rankingnya. Hal tersebut ditampilkan pada tabel berikut: 
Tabel 5. Nilai Performance dan ranking alternative

\begin{tabular}{|c|c|c|c|c|c|c|c|c|c|}
\hline \multirow{2}{*}{ Alternatif } & \multicolumn{7}{|c|}{ Kriteria } & \multirow{2}{*}{ Pn } & \multirow{2}{*}{ Rangking } \\
\cline { 2 - 9 } & KO & KB & PM & BP & RP & KK & KP & & \\
\hline \hline Awal & 42.84 & 27.18 & 25.91 & 14.75 & 41.53 & 22.02 & 48.39 & 222.61 & 8 \\
\cline { 2 - 9 } 1 & 94.99 & 30.20 & 41.78 & 23.04 & 50.43 & 28.98 & 93.19 & 362.62 & 4 \\
\hline 2 & 63.33 & 27.18 & 28.41 & 15.67 & 42.52 & 22.60 & 51.97 & 251.68 & 7 \\
\hline 3 & 67.05 & 28.99 & 30.92 & 16.59 & 45.48 & 22.60 & 64.52 & 276.16 & 6 \\
\hline 4 & 93.13 & 30.81 & 42.62 & 23.51 & 52.40 & 29.56 & 93.19 & 365.21 & 3 \\
\hline 5 & 96.86 & 30.20 & 43.46 & 23.04 & 52.40 & 28.98 & 93.19 & 368.13 & 2 \\
\hline 6 & 76.37 & 28.39 & 28.41 & 16.59 & 45.48 & 23.18 & 62.72 & 281.15 & 5 \\
\hline 7 & 113.62 & 31.41 & 50.98 & 27.19 & 59.33 & 34.19 & 111.11 & 427.83 & 1 \\
\hline 8 & 42.84 & 27.79 & 22.56 & 13.37 & 36.58 & 14.49 & 39.43 & 197.05 & 9 \\
\hline
\end{tabular}

Untuk menggambarkan dengan bentuk lain maka grafik berikut ini dapat menjadi alat untuk mengetahui nilai dan peringkat performance dari masing-masing alternatif.

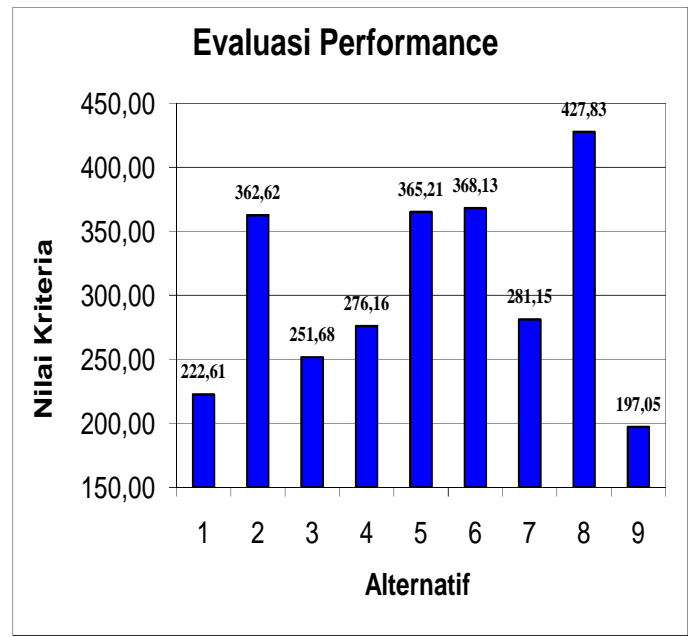

Gambar 2 Grafik Peringkat Performance

\subsection{Analisa Biaya}

Analisa biaya merupakan pendukung untuk dapat menilai alternatif secara keseluruhan. Selain performance, biaya juga perlu diketahui sampai seberapa besar diperlukan untuk memodifikasi Tungku gasifikasi biomassa tersebut, biaya yang diperhitungkan adalah meliput biaya bahan baku dan biaya pengerjaan.

\subsection{Penentuan Nilai (Value Engineering)}

Dalam menentukan besarnya nilai pada alternatif modifikasi dilakukan dengan membandingkan antara performansi (P) dengan biaya yang dikeluarkan dalam memodifikasi Tungku Briket arang biomassa.

Berdasarkan analisa yang diperoleh dengan mengambil patokan alternatif awal sebagai alternatif yang memiliki nilai (value) $=1$, dan dengan rumus
Value $=\frac{\text { Performanc e }}{\text { Cost }}$ maka diperoleh nilai (value) masing-masing alternatif berikut:

Tabel 6 Rekapitulasi Value dan nilai (value) yang diperoleh

\begin{tabular}{|c|cc|c|c|}
\hline Alternatif & \multicolumn{2}{|c|}{ Cn } & Pn & Vn \\
\hline Awal (0) & $\operatorname{Rp}$ & $1,100,000$ & 222.61 & 1.000 \\
\hline 1 & $\operatorname{Rp}$ & $1,600,000$ & 362.62 & 1.120 \\
\hline 2 & $\operatorname{Rp}$ & $1,150,000$ & 251.68 & 1.081 \\
\hline 3 & $\operatorname{Rp}$ & $1,300,000$ & 276.16 & 1.050 \\
\hline 4 & $\operatorname{Rp}$ & $1,650,000$ & 365.21 & 1.094 \\
\hline 5 & $\operatorname{Rp}$ & $1,800,000$ & 368.13 & 1.011 \\
\hline 6 & $\operatorname{Rp}$ & $1,350,000$ & 281.15 & 1.029 \\
\hline 7 & $\operatorname{Rp}$ & $1,850,000$ & 427.83 & 1.143 \\
\hline 8 & $\operatorname{Rp}$ & 900,000 & 197.05 & 1.082 \\
\hline
\end{tabular}

Hasil perhitungan nilai (value) tiap alternatif tersebut dapat juga ditunjukkan dalam grafik sebagai berikut :

Gambar 3 Grafik Peringkat Value

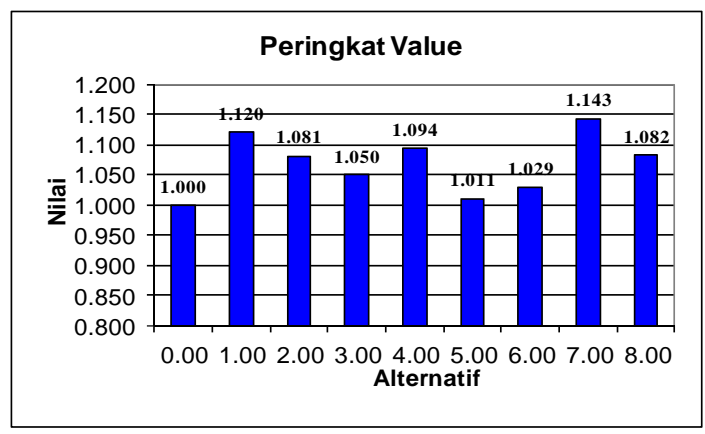

\section{KESIMPULAN}

Berdasarkan analisis dan pembahasan yan telah dilakukan, diperoleh bahwa alternatif modifikasi ke-7,mempunyai nilai tertinggi yaitu1,142 dengan performansi 427,83, dan biaya Rp.1.850.000,0. Alternatif ini memberikan keuntungan antara lain, kemudahan operasionalnya sangat meningkat dapat dilakukan pengisian berulang tanpa mengganggu nyala api 
(sistem kontinyu), dan pemadaman api dapat dilakukan dengan cepat tanpa pembongkaran tungku (semi otomatis), pengguna tidak perlu memasak diatas reaktor gasifikasi yang panas dan tinggi, karena tungku ini didesain dapat memasak diatas burner yang jauh dari reaktor gasifikai, kecepatan pemasakan meningkat (mendidihkan 2 It air dengan waktu 7 menit), pencemaran menurun dan tidak terjadi bau menyengat. Disamping itu, Tungku gasifikasi multiburner mempunyai nilai ekonomi tinggi karena kinerjanya hampir sama dengan tungku minyak tanah dan biaya operasionalnya sekitar $1 / 3$ dari tungku minyak tanah, untuk memasak 2 It air, menggunakan minyak tanah sekitar $1 / 10$ It (Rp. 1300), dengan tungku single burner membutuhkan sekam $3 \mathrm{~kg}$ (Rp. 750) dan dengan tungku ini membutuhkan $2 \mathrm{~kg}$ sekam (Rp.500), dengan melihat hal tersebut, maka tungku gasifikasi multibuerner, dari segi ekonomi sangat prospek untuk dikembangkan di masyarakat. Sebagai salah satu alternative pengganti tungku gasifikasi single burner, tungku minyak tanah dan kayu bakar dan sebagai salah satu agen dari green technology guna menciptakan masyarakat mandiri energi khususnya di pulau-pulau kecil

\section{Prospek pengembangan}

Mengingat kebutuhan energi untuk memasak skala rumah tangga terkandala dengan biaya dan ketersediaan minyak tanah, maka dengan dihasilkannya desain tungku gasifikasi multiburner modifikasi ini, yang memiliki banyak kelebihan yaitu kemudahan operasionalnya sangat meningkat dapat dilakukan pengisian berulang tanpa mengganggu nyala api (sistem kontinyu), dan pemadaman api dapat dilakukan dengan cepat tanpa pembongkaran tungku (semi otomatis), pengguna tidak perlu memasak diatas reaktor gasifikasi yang panas dan tinggi, karena tungku ini didesain dapat memasak diatas burner yang jauh dari reaktor gasifikai, kecepatan pemasakan meningkat (mendidihkan 2 It air dengan waktu 7 menit), pencemaran menurun dan tidak terjadi bau menyengat disamping itu, tungku gasifikasi multiburner mempunyai nilai ekonomi tinggi karena kinerjanya hampir sama dengan tungku minyak tanah dan biaya operasionalnya sekitar $1 / 3$ dari tungku minyak tanah, untuk memasak 3 It air, menggunakan minyak tanah sekitar $1 / 10$ It (Rp. 1300), dengan tungku single burner membutuhkan sekam 2 kg (Rp. 400) dan dengan tungku ini membutuhkan $2 \mathrm{~kg}$ sekam (Rp.400), dengan melihat hal tersebut, maka tungku gasifikasi multibuerner, dari segi ekonomi sangat prospek untuk dikembangkan di masyarakat. Sebagai salah satu alternative pengganti tungku gasifikasi single burner, tungku minyak tanah dan kayu bakar dan sebagai salah satu agen dari green technology guna menciptakan masyarakat mandiri energi khususnya di pulau-pulau kecil.

\section{Daftar Pustaka}

[1] Hummaidi, M , 2006, Pemanfaatan sekam padi menjadi bahan dasar pembuatan briket bioarang sebagai bahan bakar alternatif pengganti bahan bakar minyak (BBM), Skripsi Teknik Mesin Unram

[2] Rachmanto,T., Wijana, M., Nurchayati, 2009, Pemanfaatan Tungku Energi Gasifikasi Sekam Padi (single burner) Sebagai Energi Alternatif Pengganti Kompor Minyak Tanah dan Tungku Kayu Bakar Menuju Masyarakat Mandiri Energi di Daerah Tertinggal Rawan Kemiskinan, Laporan Pengabdian, LPM Unram

[3] (Heller, 1971) 